\title{
Inhibition of actin polymerization by marine toxin pectenotoxin-2
}

\author{
Masatoshi HORI)\#* , Futoshi YAZAMA ${ }^{2) \#, ~ Y a s u h i r o ~ M A T S U U R A ~}{ }^{1)}$, \\ Ryo YOSHIMOTO'), Takeharu KANEDA ${ }^{3)}$, Takeshi YASUMOTO4), \\ Hiroshi OZAKI ${ }^{1)}$ and Hideaki KARAKI ${ }^{1)}$
1)Department of Veterinary Pharmacology, Graduate School of Agriculture and Life Sciences, The University of Tokyo, Bunkyo-ku, Tokyo 113-8657, Japan
2) Laboratory of Cell Biology and Morphology, School of Bioresources Hiroshima Prefectural University, Shoubara-shi, Hiroshima 727-0023, Japan University, 1-7-1 Kyonan-cho, Musashino, Tokyo 180-8602, Japan \\ 3)Laboratory of Veterinary Pharmacology, School of Veterinary Medicine, Nippon Veterinary and Life Science \\ 4) Japan Food Research Laboratories, 6-11-10 Nagayama, Tama, Tokyo 206-0025, Japan
}

\section{J. Vet. Med. Sci.}

80(2): $225-234,2018$

doi: 10.1292/jvms.17-0654

Received: 4 December 2017 Accepted: 17 December 2017 Published online in J-STAGE: 26 December 2017
ABSTRACT. Pectenotoxin-2 (PCTX-2) is one of the polyether macrolide toxins isolated from scallops involved in diarrheic shellfish poisoning via actin depolymerization. In the present study, we examined the bioactive mechanism of PCTX-2 in smooth muscle cells and clarify mode of action of the PCTX-2-induced actin depolymerization using purified skeletal actin. PCTX-2 ( $300 \mathrm{nM}-3 \mu \mathrm{M}$ ) non-selectively inhibited vascular smooth muscle contractions elicited by high $\mathrm{K}^{+}$or phenylephrine in a dose-dependent manner. However, elevated cytosolic $\mathrm{Ca}^{2+}$ and myosin light chain phosphorylation stimulated by high $\mathrm{K}^{+}$were only slightly inhibited by PCTX-2. By monitoring the fluorescent intensity of pyrenyl-actin, PCTX-2 was found to inhibit both the velocity and degree of actin polymerization. The critical concentration of G-actin was linearly increased in accordance with the concentration of PCTX-2, indicating sequestration of G-actin with 1 to 1 ratio. The kinetics of F-actin depolymerization by dilution assay indicated that PCTX-2 does not sever F-actin. Transmission electron microscopic and confocal microscopic observations demonstrated that PCTX-2 selectively depolymerized filamentous actin without affecting tublin. In conclusion, PCTX-2 is a potent natural actin depolymerizer which sequesters G-actin without severing F-actin.

KEY WORDS: actin depolymerization, aorta, macrolide, marine toxin, pectenotoxin

Pectenotoxin-2 (PCTX-2; Fig. 1) belongs to a family of polyether macrolide toxins isolated from the digestive glands of the scallop Patinopecten yessoensis in Northeastern Japan [5, 19, 29, 30]. PCTXs were also purified from marine sponges, Poecillastra sp. and Jaspis sp., collected on Cheju and Komun islands in Korea [7]. Using a rapid HPLC method with fluorescence detection, PCTX-2 was detected in net haul samples mostly composed of dinoflagellates Dinophysis spp. collected in the Adriatic Sea, Italy and Mutsu Bay, Japan [20]. Among the toxins of this family, PCTX-1, PCTX-2, PCTX-3 and PCTX-6 share the common skeleton with the only difference at $\mathrm{C}-43$ where all stages of oxidation from methyl to carboxylic acid are found $\left(\mathrm{PCTX}^{-1,} \mathrm{CH}_{2} \mathrm{OH}\right.$; $\mathrm{PCTX}-$ $2, \mathrm{CH}_{3}$; PCTX-3, $\mathrm{CHO}$; and PCTX-6, $\left.\mathrm{COOH}\right)$.

PCTXs have been shown to be involved in diarrheic shellfish poisoning. Histopathological investigations have revealed that PCTX-1 is hepatotoxic and induces rapid necrosis of hepatocytes [11, 25, 29]. From the structural similarity between PCTX-1 and PCTX-2, PCTX-2 was also suggested to be a hepatotoxin. Moreover, it was discovered that PCTX-2 displays a potent cytotoxic activity against not only hepatocytes but also human lung, colon and breast cancer cell lines [7]. Accumulating studies revealed that PCTX-2 acts on actin molecule to depolymerize actin fiber in skeletal, cardiac and smooth muscle cells and non-muscle cells $[2,3]$. However, detailed biological and biophysical mechanism of PCTX-2 on actin depolymerization is not well investigated. The aim of this study was to clarify the bioactive mechanism of PCTX-2 in vascular smooth muscle contractility and also identify mode of action of PCTX-2 on actin depolymerization.

\footnotetext{
*Correspondence to: Hori, M: ahori@mail.ecc.u-tokyo.ac.jp

\#These authors contributed equally to this work.

(O2018 The Japanese Society of Veterinary Science
}

This is an open-access article distributed under the terms of the Creative Commons Attribution Non-Commercial No Derivatives (by-nc-nd) License. (CC-BY-NC-ND 4.0: https://creativecommons.org/licenses/by-nc-nd/4.0/) 


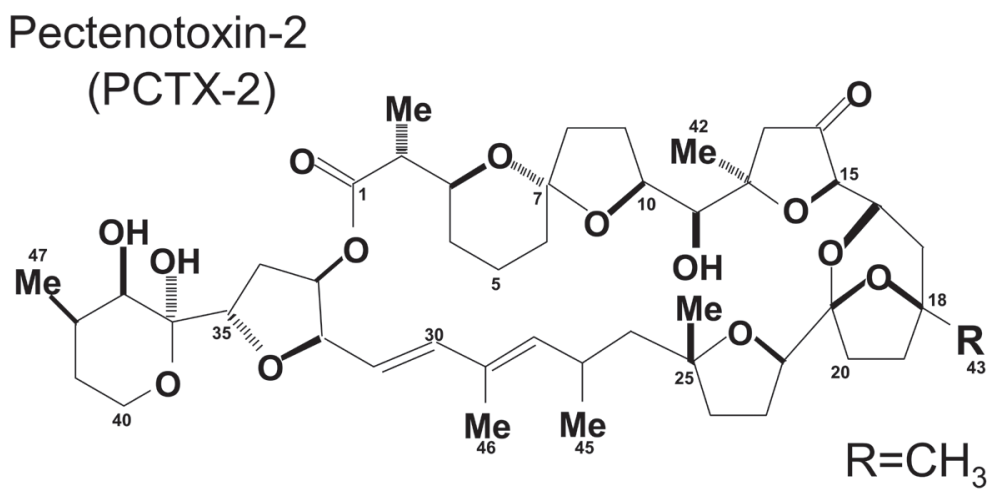

Fig. 1. Chemical structure of pectenotoxin-2 (PCTX-2). Pectenotoxin-2 (PCTX-2) is one of a family of polyether macrolide marine toxins.

\section{MATERIALS AND METHODS}

\section{Isometric force measurement in rat aorta}

Male Wistar rats were stunned and sacrificed in accordance with the use and treatment of animals outlined in the Guide to Animal Use and Care of the University of Tokyo. The thoracic aorta was isolated and cut into rings of 2-3 mm width. Isolated muscle strips were placed in physiological salt solution (PSS) which contained (in mM): $\mathrm{NaCl} 136.9, \mathrm{KCl} 5.4, \mathrm{CaCl}_{2} 1.5, \mathrm{MgCl}_{2}$ 1.0, $\mathrm{NaHCO}_{3} 23.8$ and glucose 5.5. EDTA $(0.01 \mathrm{mM})$ was also added to chelate the contaminating heavy metal ions. Endothelium was removed by gently rubbing the intimal surface with a glass rod moistened with PSS. High $\mathrm{K}^{+}(72.7 \mathrm{mM})$ solution was made by replacing $\mathrm{NaCl}$ with equimolar $\mathrm{KCl}$. These solutions were saturated with $95 \% \mathrm{O}_{2}$ and $5 \% \mathrm{CO}_{2}$ mixture at $37^{\circ} \mathrm{C}$ to maintain the $\mathrm{pH}$ at 7.4. Muscle preparations were attached to a holder under resting tension of $10 \mathrm{mN}$ and equilibrated for $60-90 \mathrm{~min}$ in PSS. The muscle force was recorded isometrically. During this recording, high $\mathrm{K}^{+}$was repeatedly applied until the peak force became reproducible.

\section{Cytosolic $\mathrm{Ca}^{2+}$ measurement}

Simultaneous measurement of muscle force and cytosolic $\mathrm{Ca}^{2+}\left(\left[\mathrm{Ca}^{2+}\right]_{\mathrm{i}}\right)$ was performed as described by Sato et al. [21] with the fluorescent $\mathrm{Ca}^{2+}$ indicator fura-2. Rat aortic strips were treated with PSS containing acetoxymethylester of fura-2 (fura-2/ $\mathrm{AM}, 5 \mu \mathrm{M})$ and the non-cytotoxic detergent, cremophor EL (0.02\%), for 4-5 hr at room temperature. After the loading of fura-2/ $\mathrm{AM}$, the muscle strips were first washed with PSS at $37^{\circ} \mathrm{C}$ for $20 \mathrm{~min}$ to remove uncleaved fura-2/AM and then held horizontally in a temperature-controlled organ bath $(7 \mathrm{ml})$. One end of the muscle strips was connected to a force-displacement transducer to monitor muscle force. Experiments were performed with a bio-fluorometer (CAF-110, Japan Spectroscopic Co., Ltd., Tokyo, Japan), and the ratio of $500 \mathrm{~nm}$ fluorescence excited at $340 \mathrm{~nm}$ (F340) to that excited at $380 \mathrm{~nm}$ (F380) (F340/F380) was used as an indicator of $\left[\mathrm{Ca}^{2+}\right]_{\mathrm{i}}$. The resting $\left[\mathrm{Ca}^{2+}\right]_{\mathrm{i}}$ and the $\left[\mathrm{Ca}^{2+}\right]_{\mathrm{i}}$ at $5 \mathrm{~min}$ after application of $72.7 \mathrm{mM} \mathrm{KCl}$ were taken as 0 and $100 \%$, respectively.

\section{Myosin light chain (MLC) phosphorylation}

The amount of MLC phosphorylation was measured according to the modified method described by Word et al. [27]. Strips of rat aorta were held isometrically under a resting tension force of $10 \mathrm{mN}$ on stainless steel holders and were quickly frozen in dry-ice acetone with 10\% trichloroacetic acid (TCA). The strips were then incubated for several hours in the acetone/TCA solution until the temperature of the solution reached approximately $0^{\circ} \mathrm{C}$; they were then crushed in the liquid nitrogen. The crushed muscle powder was suspended in 10\% TCA and $10 \mathrm{mM}$ dithiothreitol (DTT, 200-400 $\mu l$ ). The homogenate was centrifuged at 10,000 $\times g$ for $10 \mathrm{~mm}$ and the pellet was washed with $500 \mu \mathrm{l}$ diethyl ether several times to remove TCA. The pellet was then suspended in urea-glycerol buffer $(25-75 \mu l)$ containing $20 \mathrm{mM}$ Tris, $23 \mathrm{mM}$ Glycine, $8 \mathrm{M}$ urea, $10 \mathrm{mM}$ DTT and 0.04\% Bromophenol Blue, and was centrifuged at $10,000 \times g$ for $15 \mathrm{~mm}$. The supernatant was used as a sample.

The phosphorylated MLC was separated using glycerol polyacrylamide gel electrophoresis (PAGE) and the MLC was measured by western blot using anti-MLC antibody (donated by Dr. J. T. Stull, University of Texas Southwestern Medical Center at Dallas). The areas of phosphorylated and unphosphorylated MLC were measured by imaging $\mathrm{J}$.

\section{Cell culture and F-actin staining}

A7r5 cells (passages 15-25), derived from rat aortic smooth muscle cells, were purchased from American Type Culture Collection (Rockville, MD, U.S.A.). The cells were grown in Dulbecco's modified Eagle's medium (DMEM) under $95 \% \mathrm{O}_{2}$ and $5 \% \mathrm{CO}_{2}$ in the presence of $10 \%$ fetal calf serum (FCS), $1.7 \mathrm{mM} \mathrm{L}$-glutamine, streptomycin $(30 \mathrm{mg} / \mathrm{m} l)$ and penicillin $(30 \mathrm{U} / \mathrm{m} l)$. Sub-confluent cells were used in each experiment. Before starting experiments, FCS was removed from the medium for $12 \mathrm{hr}$. After DMEM without FCS was changed to PSS at $37^{\circ} \mathrm{C}$, vehicle $(0.01 \%$ ethanol $)$ or PCTX-2 $(300 \mathrm{nM}$ and $1 \mu \mathrm{M})$ was added. After 
incubation for $15 \mathrm{~min}$ at $37^{\circ} \mathrm{C}$, the F-actin was stained using FITC-phalloidin. Briefly, the cells were rinsed with PHEM buffer which contained (in mM) PIPES, 60; HEPES, 25; EGTA, 10 and $\mathrm{MgCl}_{2}, 2$ at $\mathrm{pH} 7.3$ at $37^{\circ} \mathrm{C}$ and treated with PHEM buffer in the presence of $3.7 \%$ formaldehyde for $15 \mathrm{~min}$ at $37^{\circ} \mathrm{C}$. Then formaldehyde was removed by washing three times for every $5 \mathrm{~min}$ using PHEM buffer at room temperature. Cell membrane was permeabilized with $0.2 \%$ Triton X-100 in PHEM buffer for 90 sec, and washed with PHEM buffer again. FITC-phalloidin $(4 \mathrm{U} / \mathrm{m} l)$ treatment was performed for $1 \mathrm{hr}$, and then washed with PHEM buffer again. The morphology of actin filament in the surface and the bottom of the cells was analyzed using confocal microscope (Carl Zeiss, LSM510). We estimated the depth of a given preparation by scanning along the z-axis to acquire a series of crosssections. Four or five images were then obtained at each depth from the surface of the cell to the bottom in increments of $1 \mu \mathrm{m}$. The effects of PCTX-2 on actin filaments stabilized during the 30 min incubation period of PCTX-2 (data not shown). We therefore examined the effects of several different concentrations of PCTX-2 on actin filaments in this incubation time. Images judged to be typical of those taken of 10-15 cells are shown. These images were taken at the bottom of the cells and at a distance of $1 \mu \mathrm{m}$ from the surface of the cell.

\section{Cell viability}

A $7 \mathrm{r} 5$ cells were cultured in DMEM with $10 \% \mathrm{FCS}$ and $1 \%$ penicillin/streptomycin. The confluent cells were treated with DMEM with $1 \%$ penicillin/streptomycin overnight. After changing the medium to PSS, PCTX-2 (100 nM and $1 \mu \mathrm{M})$ or vehicle $\left(0.3 \%\right.$ ethanol) was added and the cells were incubated at $37^{\circ} \mathrm{C}$ for $30 \mathrm{~min}$. The cells were then collected using $0.05 \%$ tripsinEDTA, and re-suspended in 0.5\% Trypan Blue in PBS (pH 7.4). Cell viability was calculated by hemocytometer.

\section{Measurements of polymerization of fluorescent pyrenyl-actin}

Skeletal actin was extracted from acetone powder of rabbit fast skeletal muscle using buffer $\mathrm{G}$ containing $0.2 \mathrm{mM} \mathrm{CaCl}_{2}$, $0.2 \mathrm{mM}$ ATP, $0.5 \mathrm{mM} \beta$-mercaptoethanol and Tris- $\mathrm{HCl}$ (pH 8.0) [23]. Crude G-actin was further purified by Sephadex G-200 gel filtration. Pyrene labeling was performed by the method described previously [26]. Actin polymerization was started by the addition of $50 \mathrm{mM} \mathrm{KCl}$ and $1 \mathrm{mM} \mathrm{MgCl} 2$ to buffer $\mathrm{G}$. The time course of polymerization (or depolymerization) was continuously monitored by measuring fluorescence of pyrenyl-actin (2.5\% of total G-actin) with a fluorometer (FP-2060, JASCO, Tokyo, Japan) at $25^{\circ} \mathrm{C}$ at $365 \mathrm{~nm}$ excitation and $407 \mathrm{~nm}$ emission wavelengths.

\section{Transmission electron microscopy}

Eight percent paraformaldehyde in distilled water with 5-8 drops of $1 \mathrm{~N} \mathrm{NaOH}, 0.2 \mathrm{M}$ phosphate buffer at $\mathrm{pH} 7.2$, and $25 \%$ of glutaraldehyde solution was prepared. The fixation solution, which contained $2 \%$ paraformaldehyde and $2.5 \%$ glutaraldehyde in the $0.1 \mathrm{M}$ phosphate buffer ( $\mathrm{pH}$ 7.2) was made from this solution. For transmission electron microscopy, cells were immersed in the fixation solution at $4^{\circ} \mathrm{C}$. The fixed cells were washed briefly in the same buffer, post-fixed with buffer containing $1 \% \mathrm{OsO}_{4}$ in the $0.1 \mathrm{M}$ phosphate buffer at $\mathrm{pH} 7.2$ for $2 \mathrm{hr}$ at $4^{\circ} \mathrm{C}$ and dehydrated through a graded ethanol series. The dehydrated cells were embedded in Epon 812 resin. Thin sections were cut using an ultramicrotome, doubly stained with uranyl acetate and lead citrate, and examined under a Hitachi H-7500 electron microscope operated at $80 \mathrm{kV}$.

\section{Chemicals}

PCTX-2, involved in diarrheic shellfish poisoning, was isolated from the digestive glands of the scallop, Patinopecten yessoensis, found in Northeastern Japan (Fig. 1). Mycalolide B was donated by Dr. Fusetani of the University of Tokyo. N-(1Pyrene)-iodoacetamide was obtained from Molecular Probes (Eugene, OR, U.S.A.).

\section{Statistics}

The numerical data were expressed as mean \pm S.E.M. Differences between mean values were evaluated by Student's $t$-test and, where appropriate, analysis of variance (one-way ANOVA; Bonferroni's test) was performed.

\section{RESULTS}

\section{Effect of PCTX-2 on force generation of intact and permeabilized muscles}

We investigated the effect of PCTX-2 on contractions elicited by $72.7 \mathrm{mM} \mathrm{KCl}$ and $1 \mu \mathrm{M}$ phenylephrine in intact rat aorta (Fig. 2). PCTX-2 inhibited both contractions in a time- and concentration- dependent manner. Based on the inhibition measured at 120 min after the addition of PCTX-2, the concentrations of PCTX-2 to induce $50 \%$ inhibition of contractions due to $72.7 \mathrm{mM} \mathrm{KCl}$ and $1 \mu \mathrm{M}$ phenylephrine were calculated to be $0.33 \mu \mathrm{M}$ and $0.29 \mu \mathrm{M}$, respectively.

In the permeabilized rabbit mesenteric artery with Triton $\mathrm{X}-100,3 \mu \mathrm{M} \mathrm{Ca}^{2+}$ induced a sustained contraction. After the $\mathrm{Ca}^{2+}-$ induced contraction reached a plateau, the addition of $3 \mu \mathrm{M}$ PCTX-2 completely inhibited the $\mathrm{Ca}^{2+}$-induced contraction (n=3, data not shown).

\section{Effects of PCTX-2 on cytosolic $\mathrm{Ca}^{2+}$}

High $\mathrm{K}^{+}(72.7 \mathrm{mM})$ induce a transient increase in $\left[\mathrm{Ca}^{2+}\right]_{\mathrm{i}}$ followed by a sustained one as shown in Fig. 3A PCTX-2 (1 $\left.\mu \mathrm{M}\right)$ inhibited $\left[\mathrm{Ca}^{2+}\right]_{\mathrm{i}}$ only slightly although it inhibited high $\mathrm{K}^{+}$-induced contraction more than $75 \%$. Figure $3 \mathrm{~B}$ shows a summary of our results, indicating that the inhibitory effect of PCTX-2 on muscle force was greater than that on $\left[\mathrm{Ca}^{2+}\right]_{\mathrm{i}}$. 
A. $72.7 \mathrm{mM} \mathrm{KCl}$

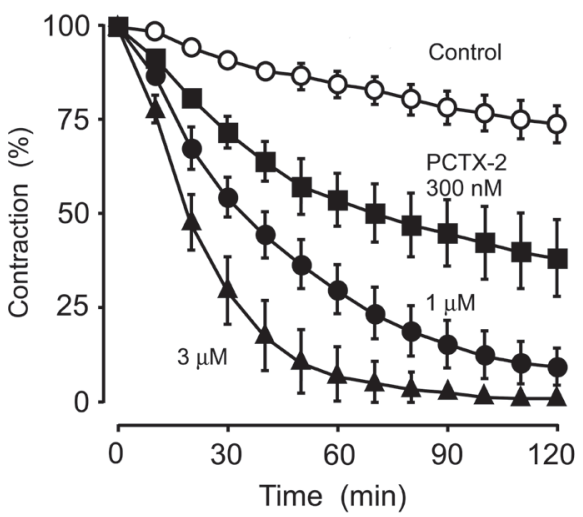

B. $1 \mu \mathrm{M}$ Phenylephrine

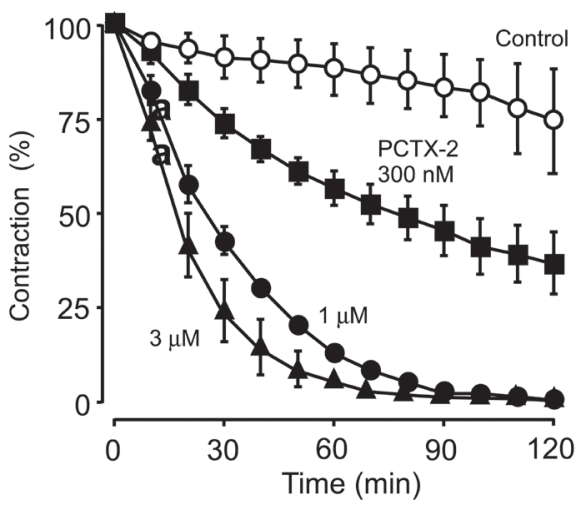

Fig. 2. Effects of PCTX-2 on contractions induced by depolarization (A) and phenylephrine (B) in vascular smooth muscle tissue. $72.7 \mathrm{mM} \mathrm{KCl}$ or $1 \mu \mathrm{M}$ phenylephrine induced monotonically sustained contraction in the rat aorta. Various concentrations (300 nM-1 $\mu \mathrm{M})$ of PCTX-2 were added after those contractions became steady state $(n=4-6)$.
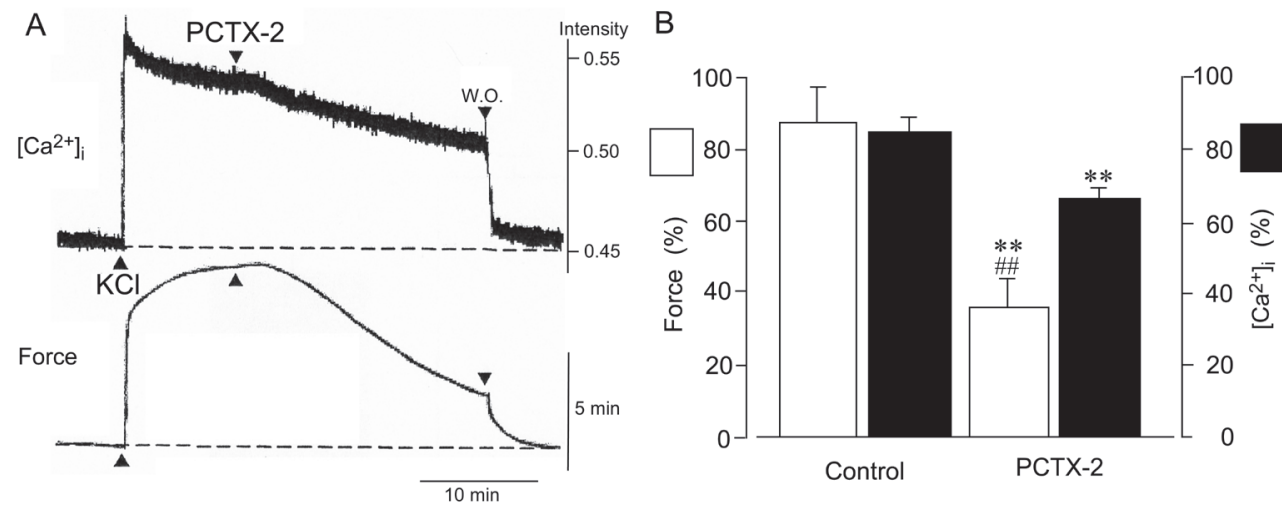

Fig. 3. Effects of PCTX-2 on muscle force and cytoplasmic $\mathrm{Ca}^{2+}$ level $\left(\left[\mathrm{Ca}^{2+}\right]_{\mathrm{i}}\right)$ stimulated with $72.7 \mathrm{mM} \mathrm{KCl}$. $72.7 \mathrm{mM} \mathrm{KCl}$-induccd increases in $\left[\mathrm{Ca}^{2+}\right]_{\mathrm{i}}$ and contraction reached a steady level at 10-15 min after stimulation. After reaching the steady state, $3 \mu \mathrm{M}$ PCTX-2 was added for $20 \mathrm{~min}$. A typical trace found in 6 experiments. B: quantitative analysis of $\left[\mathrm{Ca}^{2+}\right]_{\mathrm{i}}$ and muscle force. The steady slate of $\left[\mathrm{Ca}^{2+}\right]_{\mathrm{i}}$ and muscle force in the presence of $72.7 \mathrm{mN} \mathrm{KCl}$ was taken as $100 \%$. Control or PCTX-2 showed the effects of ethanol $(0.01 \%)$ and PCTX-2 $(3 \mu \mathrm{M})$ at $20 \mathrm{~min}$ in rat aorta. **showed significantly different from Control at $P<0.01(\mathrm{n}=4$ each). ${ }^{\#}$ showed significantly different between force and $\left[\mathrm{Ca}^{2+}\right]_{\mathrm{i}}$ in the presence of PCTX-2 at $P<0.01$ (n=4 each).

\section{Effects of PCTA-2 on myosin light chain phosphorylation}

Figure 4 shows the effects of PCTX-2 $(1 \mu \mathrm{M})$ on MLC phosphorylation stimulated with high $\mathrm{K}^{+}$. At 20 min after stimulation, MLC phosphorylation was increased by high $\mathrm{K}^{+}$from $15.4 \pm 1.45 \%$ to $41.2 \pm 1.22 \%$ ( $\mathrm{n}=4$ each). In the presence of $1 \mu \mathrm{M}$ PCTX-2, MLC phosphorylation was slightly but significantly inhibited $(34.1 \pm 1.37 \%, \mathrm{n}=4, P<0.05)$.

\section{Effect of PCTA-2 on cell viability in A7r5 cells}

In the confluent condition, the viability of $\mathrm{A} 7 \mathrm{r} 5$ cells was found to be $80.50 \pm 3.15 \%(\mathrm{n}=4)$ in the presence of vehicle $(0.3 \%$ ethanol). Cell viability did not change in the presence of $100 \mathrm{nM}$ PCTX-2 (79.01 $\pm 1.92 \%, 30$ min treatment, $\mathrm{n}=8)$ or $1 \mu$ M PCTX$2(81.57 \pm 2.40 \% .30$ min treatment, $\mathrm{n}=8)$.

\section{Effects of PCTX-2 on actin stress fiber formation in A7r5 cells using confocal microscope}

In liver cells, PCTX-1 has been reported to rearrange stress fiber formation and to result in accumulation of actin filaments at the cellular peripheries [31]. Since this report indicates the possibility that PCTX-2 may affect filamentous actin to induce muscle relaxation, we next examined the effects of PCTX-2 on actin stress fiber formation using A7r 5 cells. In the control cells, filamentous actin stress fibers were observed by FITC-phalloidin staining at the surface and the bottom of the cells (Fig. 5). After 


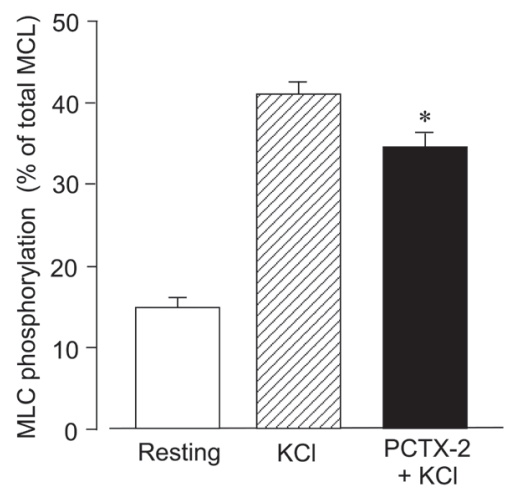

Fig. 4. Effects of PCTX-2 on high $\mathrm{K}^{+}$-induced MLC phosphorylation. Myosin light chain phosphorylation at $20 \mathrm{~min}$ after stimulation with $72.7 \mathrm{mM} \mathrm{KCl}$ was measured in the presence or absence of $1 \mu \mathrm{M}$ PCTX-2. PCTX-2 was added 15 min before the application of $72.7 \mathrm{mM} \mathrm{KCl}$. Each column shows mean $\pm \mathrm{SEM}$ (n=4 each). *: $P<0.05$ vs. $\mathrm{KCl}$.

\section{Control}
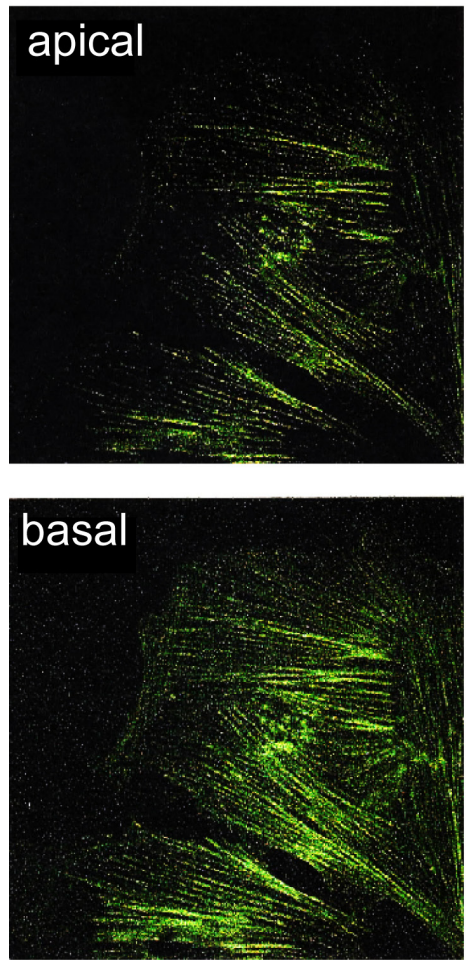

+PCTX-2 $300 \mathrm{nM}$
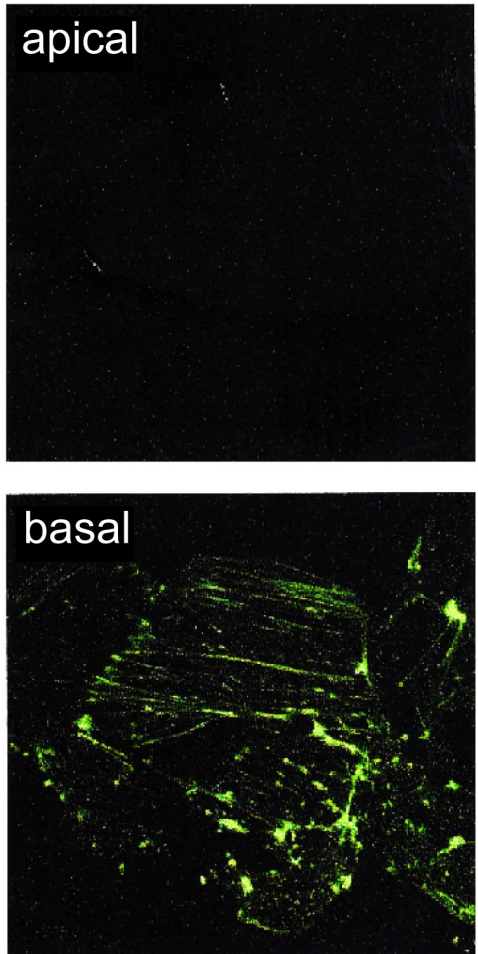

+PCTX-2 $1 \mu \mathrm{M}$
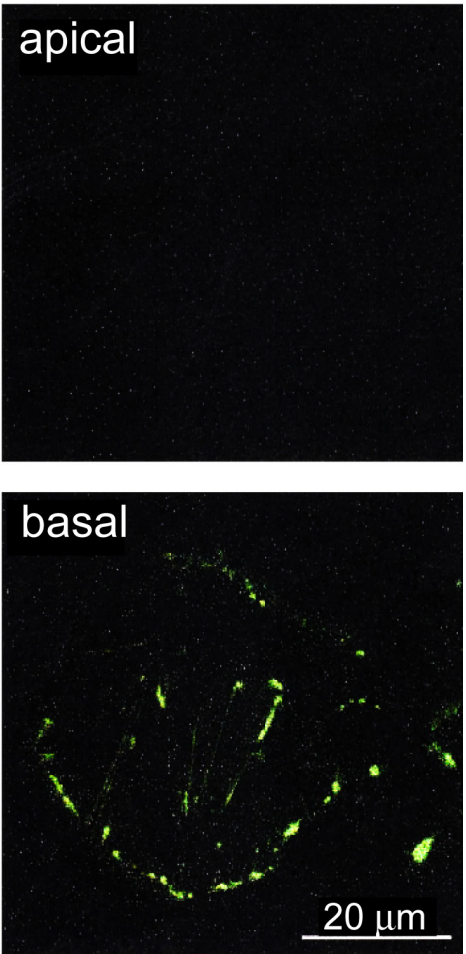

Fig. 5. Effects of PCTX-2 on actin stress fiber formation in A7r5 cells. FITC-phalloidin staining was performed with A7r5 cells in the presence or absence of PCTX-2 (300 nM, and $1 \mu \mathrm{M})$. A7r5 cells were fixed at 30 min after the addition of PCTX-2. The method used is described in detail in the Material and Method section above. Typical pictures from 3 experiments are shown. Bar indicates $20 \mu \mathrm{m}$.

30 min incubation with PCTX-2 (300 nM), F-actin fibers were completely disrupted in the apical surface, while basal actin fibers changed only slightly. In the presence of $1 \mu \mathrm{M}$ PCTX-2, basal actin fibers were further depolymerized, but still existed in basal site.

\section{Effects of PCTX-2 on actin polymerization}

We further examined whether PCTX-2 directly inhibits the actin polymerization. In the analysis of pyrenyl-actin fluorescence, addition of $1 \mathrm{mM} \mathrm{MgCl}_{2}$ polymerized $5 \mu \mathrm{M} \mathrm{G}$-actin (Fig. 6A). The maximum actin polymerization was obtained at 30-40 min 
A

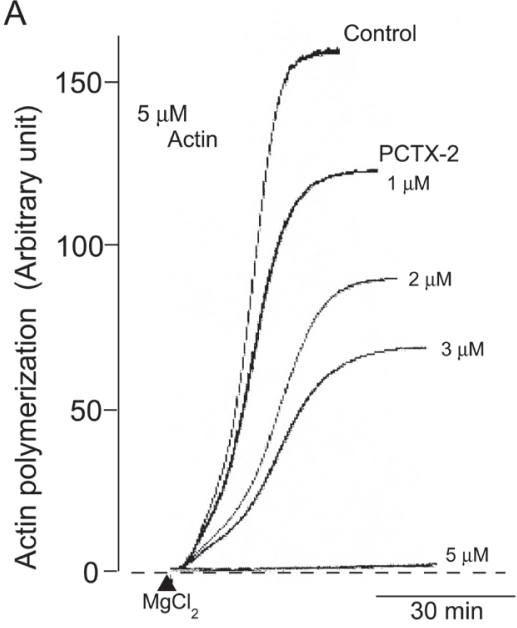

B

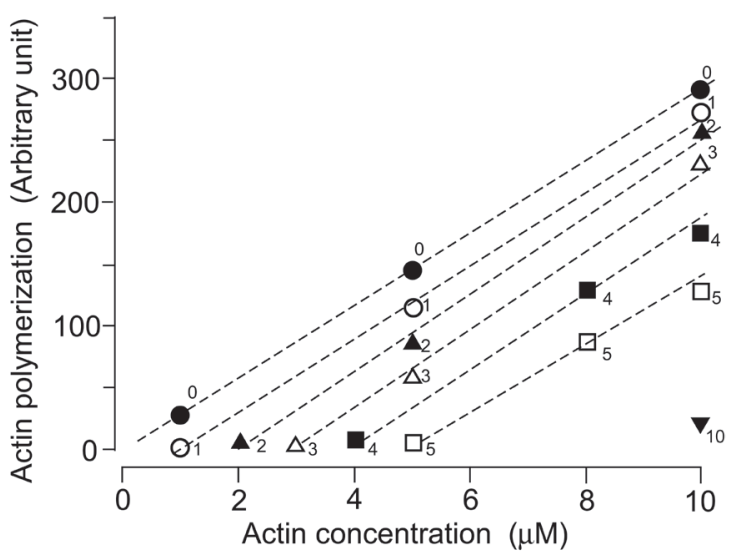

Fig. 6. Effects of PCTX-2 on the polymerization of pyrenyl-actin. Pyrenyl-actin $(1-10 \mu \mathrm{M})$ was treated with or without various concentrations of PCTX-2 (1-10 $\mu \mathrm{M})$ for $30 \mathrm{~min}$ before beginning polymerization at $0 \mathrm{~min} . \mathrm{MgCl}_{2}(1 \mathrm{mM})$ was added to start actin polymerization. The vertical bar in panel A shows the arbitrary units of increased fluorescent intensity. Panel A shows a typical tracing of the effects of PCTX-2 $(1,2,3,5 \mu \mathrm{M})$ on $5 \mu \mathrm{M}$ actin polymerization. Panel B shows the relationship between actin polymerization and actin concentration in the presence or absence of various concentrations of PCTX-2 (1-10 $\mu \mathrm{M}$ indicating small number in the figure).

after the addition of $\mathrm{MgCl}_{2}$. When PCTX-2 (1-5 $\left.\mu \mathrm{M}\right)$ was added at 10 min before the addition of $\mathrm{MgCl}_{2}$, actin polymerization induced by $\mathrm{MgCl}_{2}$, was inhibited both in velocity and in degree in a concentration-dependent manner. The inhibition of actin polymerization was plotted against variable actin concentrations $(1-10 \mu \mathrm{M})$ in the absence or presence of various concentrations of' PCTX-2 (1-10 $\mu \mathrm{M})$ (Fig. 6B) and our results indicated an inverse linear proportion.

\section{Mode of action of PCTX-2 to depolymerize F-actin}

Figure 7 shows the effects of PCTX-2 $(2 \mu \mathrm{M})$ and cytochalasin D $(5 \mu \mathrm{M})$ on pyrenyl-actin polymerization $(5 \mu \mathrm{M}$ actin). In the presence of $2 \mu \mathrm{M}$ PCTX-2, the initial velocity of actin polymerization was decreased. On the other hand, initial velocity of actin polymerization was enhanced by adding $5 \mu \mathrm{M}$ cytochalasin $\mathrm{D}$, although a degree of polymerization was significantly inhibited.

Figure 8 shows the effects of PCTX-2 on spontaneous depolymerization of F-actin by the dilution method [10]. Actin (12 $\mu \mathrm{M})$ containing pyrenyl-actin was pre-polymerized with $50 \mathrm{mM} \mathrm{KCl}$ and $1 \mathrm{mM} \mathrm{MgCl}$. Excess and rapid dilution of F-actin induced actin depolymerization spontaneously not only from the pointed end but also from the barbed end [10]. Dilution of the F-actin 160 times (final actin concentration: $75 \mathrm{nM}$ ) caused spontaneous actin depolymerization. When F-actin solution was diluted by 160 times in the presence of $75 \mathrm{nM}$ mycalolide $\mathrm{B}$, which is a typical actin severing compound, the spontaneous F-actin depolymerization was accelerated (data not shown). In contrast, the dilution-treatment with $93.75 \mathrm{nM}$ PCTX-2 did not change the velocity of the spontaneous depolymerization. When the F-actin $(12 \mu \mathrm{M})$ was pre-treated with PCTX-2 (15 $\mu \mathrm{M})$ for 15 min before the dilution, the initial fluorescent intensity was decreased more than $50 \%$ of control. In this condition, velocity of the spontaneous depolymerization by subsequent dilution treatment did not change compared with control.

\section{Effects of PCTX-2 on filamentous actin ultrastructure in A7r5 cells}

The effects of actin-depolymerizing compounds on the ultrastructure of filamentous actin in A7r5 cells were examined using electron microscopy. A comparison with the control cells shows that PCTX-2 (100 nM, 30 min treatment) changed the apical plasma membranes into an indented surface without changing the cell shape (Figs. 9A and 10A). Many actin fibers were observed under the basal plasma membrane forming focal adhesion (Fig. 9C and 9D, open arrowhead and asterisk). In addition, in A7r5 cells, actin stress fibers were also found within the apical cytoplasm. The apical stress fibers were associated with apical plasma membrane via a mat of electron-dense materials (Fig. 9B, open arrowhead); however, in the PCTX-2-treated cells, the mat of electron-dense materials of the apical surface was not visible (Fig. 10B). On the other hand, actin fibers were still recognized in the basal cytoplasm although the density was weaker than that of control cells (Fig. 10C and 10D). The apical plasma membrane showed an abnormal indented surface. As shown in Figs. 9D and 10D, microtubule filaments did not change in either the control or the PCTX-2-treated cells.

\section{DISCUSSION}

In the present study, we found that PCTX-2 isolated from the digestive glands of diarrhetic scallop, Patinopecten yessoensis, is 


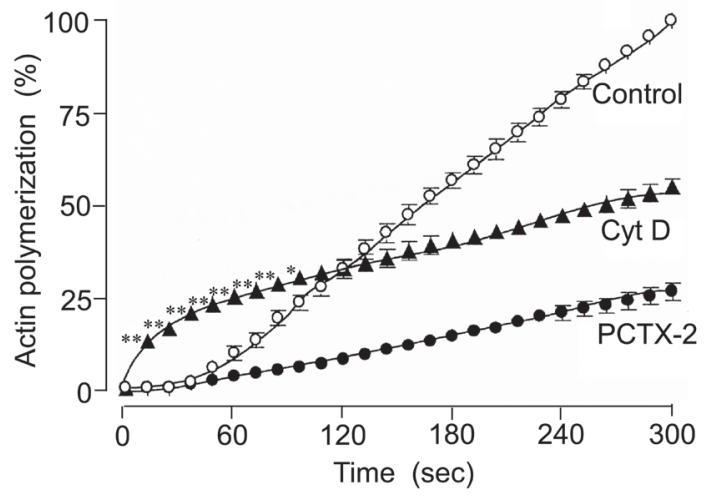

Fig. 7. Effects of cytochalasin D and PCTX-2 on the polymerization of pyrenyl-actin. Pyrenyl-actin $(5 \mu \mathrm{M})$ was treated with or without PCTX-2 $(3 \mu \mathrm{M})$ or cytochalasin D $(5 \mu \mathrm{M})$ for 30 min before starting polymerization. $\mathrm{MgCl}_{2}(1 \mathrm{mM})$ was added to start actin polymerization at $0 \mathrm{sec}$. The vertical bar shows a relative actin polymerization. Fluorescent intensity of pyrenyl-actin at $300 \mathrm{sec}$ after the addition of $1 \mathrm{mM} \mathrm{MgCl}_{2}$ was taken as $100 \%$. ${ }^{*}$ and $* *$ indicate a significant difference from Control at $P<0.05$ and $P<0.01$, respectively (n=4 each).
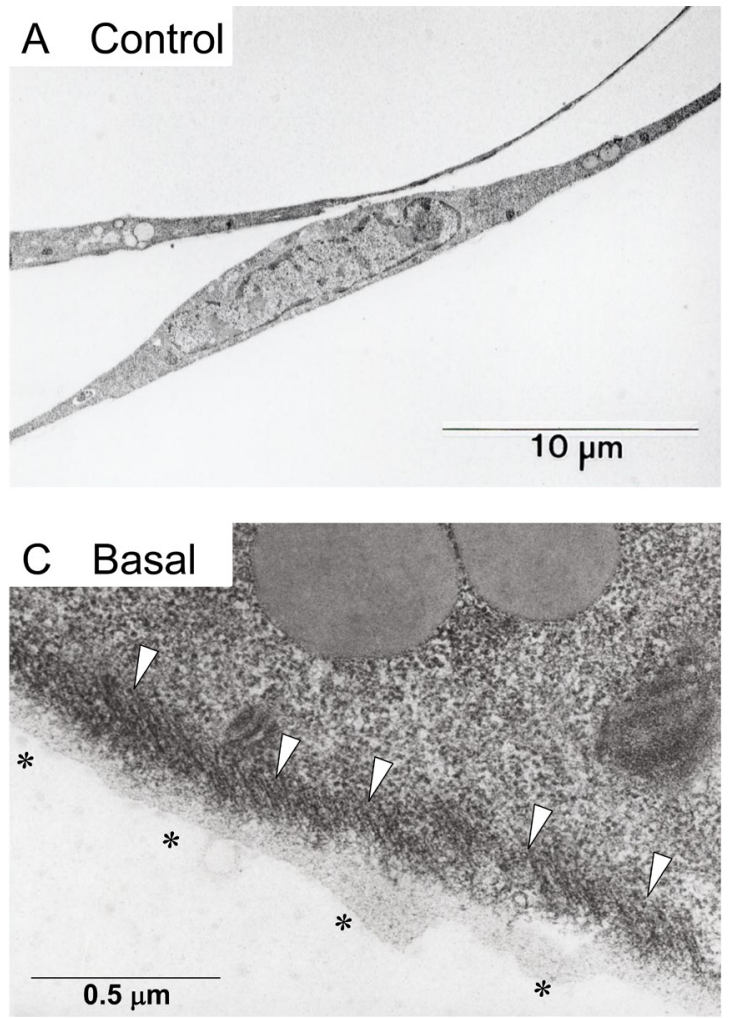

Fig. 8. The severing activity of PCTX-2 on filamentous actin using the dilution method. F-actin $(12 \mu \mathrm{M})$ was diluted 160 times with buffer $\mathrm{G}$ in the presence (closed circle) or absence (open circle) of PCTX-2 (93.75 nM). The final F-actin concentration was $75 \mathrm{nM}$. The square symbol shows that the 160-times dilution was performed after pretreatment of $\mathrm{F}$ actin $(12 \mu \mathrm{M})$ with $15 \mu \mathrm{M}$ PCTX-2 for $15 \mathrm{~min}$. Typical results from three experiments are shown.
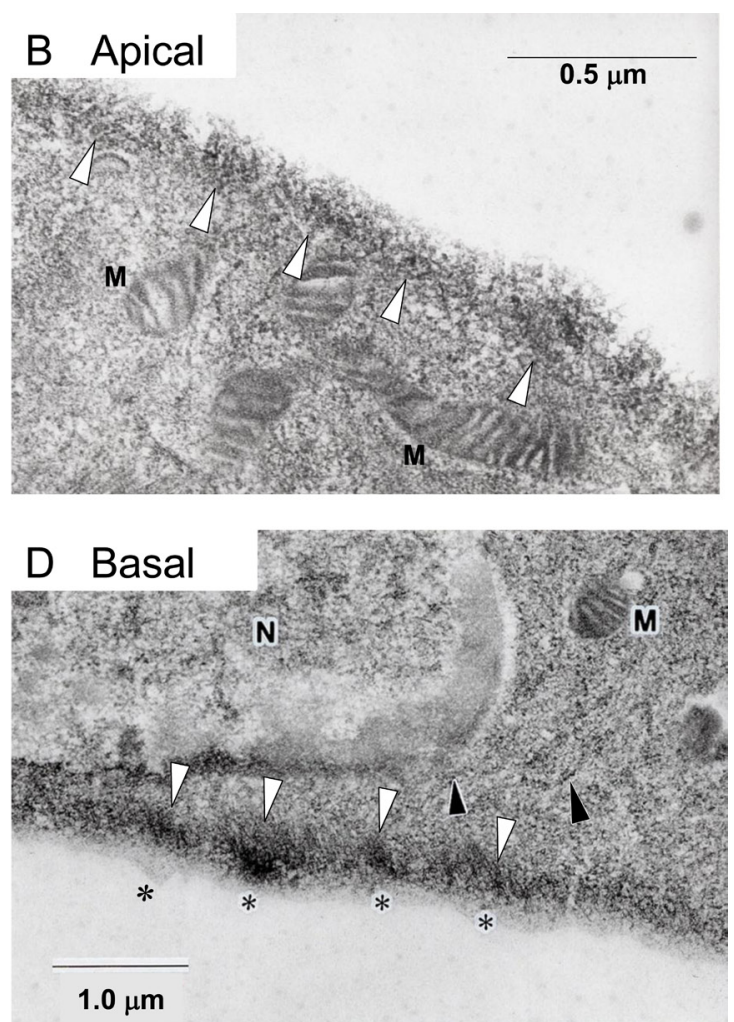

Fig. 9. Ultrastructure (A) and high (B-D) magnification in A7r5 cells. The open arrowheads and the asterisks in the basal membrane (C and D) show the forming focal adhesion containing actin filaments. The open arrowhead in the apical (B) and basal (D) plasma membrane show the apical and basal actin filaments associated with the apical and basal plasma membrane via a mat of electron-dense materials, respectively. The closed arrowheads in $\mathrm{D}$ indicates microtubules. The bar indicates $10 \mu \mathrm{m}$ in $\mathrm{A}, 0.5 \mu \mathrm{m}$ in $\mathrm{B}, \mathrm{C}$ and $1.0 \mu \mathrm{m}$ in D. Tvpical pictures are shown from 10 different cells. N: nuclei. M: mitochondria. 

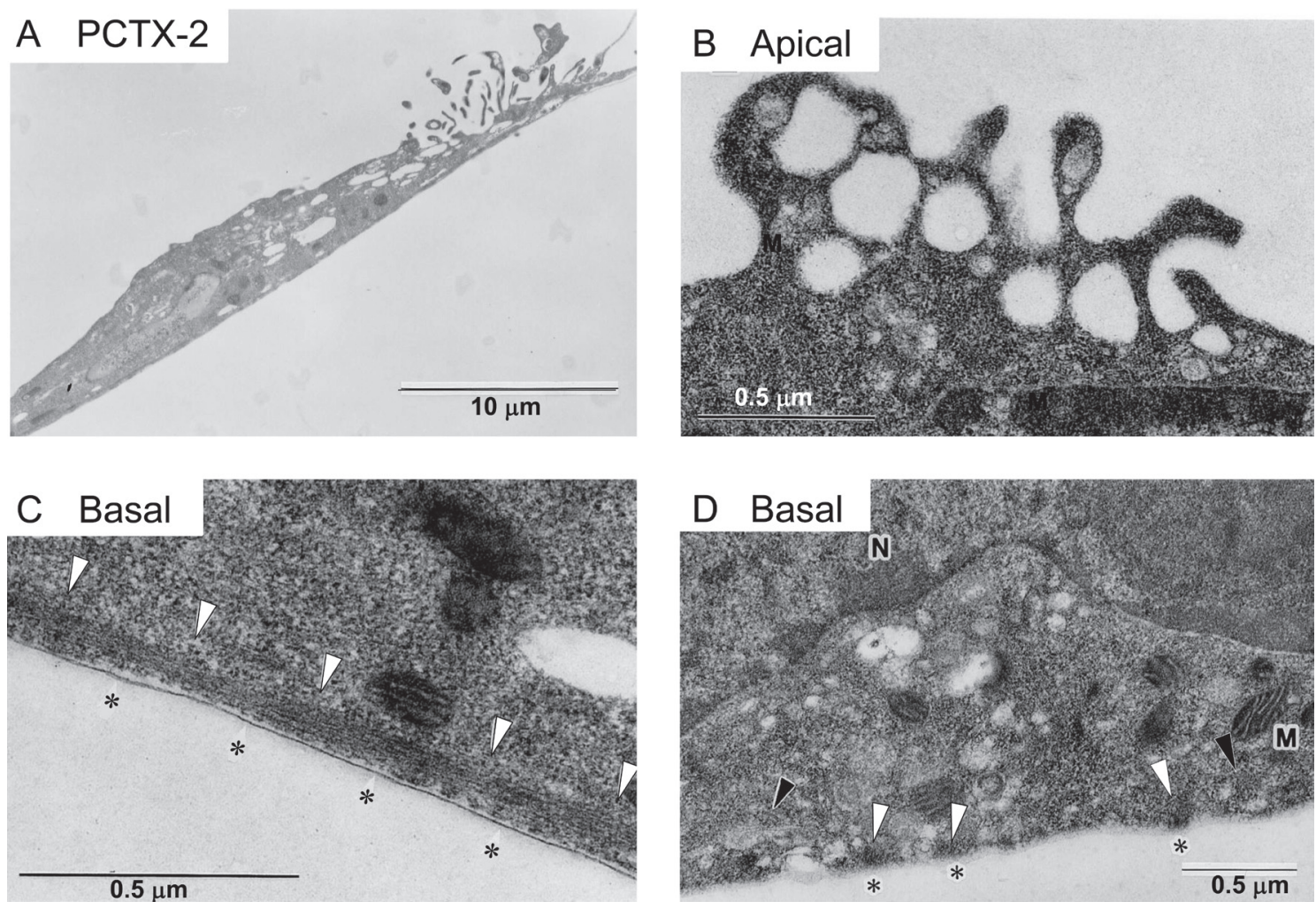

Fig. 10. Ultrastructure of 1ow (A) and high (B-D) magnification of A7r5 cells treated with PCTX 2. Th. typical ultrastructures of A7r5 cells in the presence of PCTX-2 (100 nM) chosen from images of at least 10 cells are shown here. After 30 min incubation with PCTX-2 at $37^{\circ} \mathrm{C}$, the cells were fixed. The open arrowheads and the asterisks in the basal membrane (C and D) show the forming focal adhesion containing actin filaments. The electron-density of actin filaments in the focal adhesion was lower than that in control cells (Fig. 9C and 9D). The apical actin filaments associated with the apical plasma membrane disappeared completely (B). The closed arrowheads in D indicates microtubules. The bar indicates $10 \mu \mathrm{m}$ in A and $0.5 \mu \mathrm{m}$ in B, C and D. Typical picture are shown at 10 different cells. N: nuclei. M: mitochondria.

an actin depolymerizing compound.

In the rat aorta (Fig. 2), PCTX-2 non-selectively inhibited the vascular contraction. In general, smooth muscle contraction is regulated by $\mathrm{Ca}^{2+}$-calmodulin-myosin light chain kinase signal transduction [8]. In fact, in the present study, high $\mathrm{K}^{+}$stimulation elevated both $\left[\mathrm{Ca}^{2+}\right]_{\mathrm{i}}$ and MLC phosphorylation as shown in Figs. 3 and 4. However, PCTX-2 only slightly inhibited the elevated $\left[\mathrm{Ca}^{2+}\right]_{\mathrm{i}}$ and MLC phosphorylation induced by high $\mathrm{K}^{+}$. In addition, in the permeabilized rabbit mesenteric artery with Triton X-100, PCTX-2 completely inhibited $\mathrm{Ca}^{2+}$-induced contraction (data not shown). Taken together, these data strongly suggest that PCTX-2 may inhibit smooth muscle contractions primarily by actin-myosin interaction. The PCTX-2-induced slight inhibition of $\left[\mathrm{Ca}^{2+}\right]_{\mathrm{i}}$ may be mediated by the regulation of voltage dependent $\mathrm{Ca}^{2+}$ channels by actin filaments [12].

It is necessary to clarify a certain point here. A previous study reports that cytochalasin D inhibits smooth muscle contractility without changing myosin phosphorylation [16]. In addition, Zhou et al. [31] state that PCTX-1, a PCTX derivative, arranges filamentous actin formation and induces the accumulation of actin at the cellular peripheries. Taken together, it will be possible that the inhibitory effect of PCTX-2 may be due to changes in filamentous actin. In fact, in the confocal microscope analysis, PCTX-2 disrupts stress fiber formation in the FITC-phalloidin staining of filamentous actin in A7r5 cells (Fig. 5).

We next performed a biochemical study to examine the direct effect of PCTX-2 on actin polymerization using purified skeletal muscle actin. An addition of $1 \mathrm{mM} \mathrm{MgCl}$ to the $5 \mu \mathrm{M}$ G-actin labeled with pyrene increased the pyrene fluorescence, indicating the actin polymerization (Fig. 6A). PCTX-2 (1-5 $\mu \mathrm{M})$ inhibited polymerization in both the velocity and degree in a concentrationdependent manner. These results suggest that PCTX-2 directly inhibits actin polymerization.

Stossel classified the molecular mechanisms of actin depolymerization by severing (or nibbling), sequestration and capping [24]. Actin binding proteins, such as gelsolin and villin, bind to the barbed end of F-actin (capping) and promote actin nucleation. Cytochalasin D also binds to the barbed end [18], and accelerates actin nucleation [6]. In the present study, cytochalasin D but not PCTX-2 shortened the initial lag phase of actin polymerization (Fig. 7) indicating that PCTX-2 does not promote actin nucleation. These results indicate a possibility that PCTX-2 may not have capping activity to depolymerize F-actin, although it has been reported the possibility of actin filament capping by PCTX-2 [1]. Further study is necessary to clarify the point.

To examine if PCTX-2 has the severing action, we then measured spontaneous depolymerization by the dilution method [10]. Excess and rapid dilution of F-actin solution induces spontaneous actin depolymerization not only from the pointed end but also 
from the barbed end. Severing F-actin results in an increased number of actin filaments. Therefore, excess and rapid dilution of F-actin in the presence of actin severing agent such as mycalolide B [15] accelerated the velocity of actin depolymerization (data not shown). Unlike mycalolide B, PCTX-2 did not change the velocity of actin depolymerization induced by the dilution of F-actin (Fig. 8), suggesting that PCTX-2 does not have a severing activity.

Under an equilibrium condition, the amount of G-actin released from the pointed ends of F-actin is the same as the amount of G-actin bound to the barbed ends of F-actin. Thus, the concentration at a steady state is apparently constant, and this concentration is termed as the critical concentration of G-actin. PCTX-2 increased the critical concentration of G-actin in a concentrationdependent manner as shown in Fig. 6B.This result indicates that PCTX-2 binds to G-actin to sequester G-actin from actin polymerization. Figure $6 \mathrm{~B}$ also indicates the relationship between the critical concentration of $\mathrm{G}$-actin and the concentration of PCTX-2. Analyzed results demonstrate that one molar PCTX-2 may sequestrate approximately one molar G-actin. X-ray crystal structure of PCTX-2 bound to actin also supports the stoichiometry of PCTX-2 with actin [1].

Electron microscopic studies indicated that, in A $7 \mathrm{r} 5$ cells, stress fibers are running under the apical plasma membrane in addition to those located under the basal plasma membrane. In the present study, PCTX-2 (100 nM) completely depolymerized actin fibers under the apical plasma membrane. In contrast, basal actin filaments remained in existence although they decreased slightly in density. Under confocal microscope analysis, a higher concentration of PCTX-2 (300 nM and $1 \mu \mathrm{M}, 30$ min treatment) gradually reduced the basal actin filaments, indicating that PCTX-2 is more sensitive to the apical actin filaments than to the basal actin filaments. This selectivity may be meditated by the membrane permeability of PCTX-2, or by the different functional contact of the apical actin filaments with plasma membrane compared with focal adhesion on the basal plasma membrane [9]. Further examination is needed to clarify this point.

We have reported the existence of a family of actin depolymerizing macrolides isolated from marine toxins including mycalolide $\mathrm{B}$, bistheonellode A, swinholide A and aplyronine [14, 15, 17]. These macrolide compounds have a common side chain structure attached to macrolide ring, which may be crucial to bind to G-actin [17]. In the present study, PCTX-2 does not have the motif structure common to macrolides and has a different mode of action from that of macrolides. On the other hand, the most typical G-actin sequestration compound latrunculin A contains a new class of 16- and 14- membered marine macrolides attached to the rare 2-thiazolidinone moiety [4, 22]. PCTX-2 does not have a common structure with latrunculin A, even though both bind to actin with a 1 to 1 ratio. A recent study by Yarmola et al. [28] reveals that latrunculin A has different actions with other actin binding proteins: latrunculin A inhibits binding by thymosin $\beta 4$ but not binding by profiling and DNase I to actin monomer, indicating that latrunculin A has effects related to the polymerization of actin as well as to monomer sequestration in living cells [13]. Further studies are necessary to examine the effects of PCTX-2 on other actin-binding proteins and on its biological action in living cells.

In conclusion, we demonstrated that PCTX-2 is a potent actin depolymerizing agent which may sequester G-actin without nucleation, capping or severing actions. In vascular smooth muscle cells, PCTX-2 reduced apical actin filaments more than basal actin filaments, resulting in inhibited output force generation with only a slight decrease in $\left[\mathrm{Ca}^{2+}\right]_{\mathrm{i}}$ and MLC phosphorylation.

ACKNOWLEDGMENTS. Dr. Futoshi Yazama passed away in December 2015. We will publish this study here, and we pray for his soul from the bottom of our heart. This work was supported by a Grant-in-Aid for Scientific Research from the Ministry of Education, Culture, and Science, Japan and a Program for Promotion of Basic Research Activities for Innovative Biosciences (BRAIN). We are grateful to Dr. J. T. Stull and K. E. Kamrn for generous gift of anti-myosin light chain antibody. We are also grateful to Dr. Fusetani for gift of mycalolide B.

\section{REFERENCES}

1. Allingham, J. S., Miles, C. O. and Rayment, I. 2007. A structural basis for regulation of actin polymerization by pectenotoxins. J. Mol. Biol. 371: 959-970. [Medline] [CrossRef]

2. Ares, I. R., Louzao, M. C., Espiña, B., Vieytes, M. R., Miles, C. O., Yasumoto, T. and Botana, L. 2007. Lactone ring of pectenotoxins: a key factor for their activity on cytoskeletal dynamics. Cell. Physiol. Biochem. 19: 283-292. [Medline] [CrossRef]

3. Butler, S. C., Miles, C. O., Karim, A. and Twiner, M. J. 2012. Inhibitory effects of pectenotoxins from marine algae on the polymerization of various actin isoforms. Toxicol. In Vitro 26: 493-499. [Medline] [CrossRef]

4. Coué, M., Brenner, S. L., Spector, I. and Korn, E. D. 1987. Inhibition of actin polymerization by latrunculin A. FEBS Lett. 213: 316-318. [Medline] [CrossRef]

5. Goto, H., Igarashi, T., Yamamoto, M., Yasuda, M., Sekiguchi, R., Watai, M., Tanno, K. and Yasumoto, T. 2001. Quantitative determination of marine toxins associated with diarrhetic shellfish poisoning by liquid chromatography coupled with mass spectrometry. J. Chromatogr. A 907: 181-189. [Medline] [CrossRef]

6. Howard, T. H. and Lin, S. 1979. Specific interaction of cytochalasins with muscle and platelet actin filaments in vitro. J. Supramol. Struct. 11: 283-293. [Medline] [CrossRef]

7. Jung, J. H., Sim, C. J. and Lee, C. O. 1995. Cytotoxic compounds from a two-sponge association. J. Nat. Prod. 58: 1722-1726. [Medline] [CrossRef]

8. Kamm, K. E. and Stull, J. T. 1985. The function of myosin and myosin light chain kinase phosphorylation in smooth muscle. Annu. Rev. Pharmacol. Toxicol. 25: 593-620. [Medline] [CrossRef]

9. Katoh, K., Masuda, M., Kano, Y., Jinguji, Y. and Fujiwara, K. 1995. Focal adhesion proteins associated with apical stress fibers of human fibroblasts. Cell Motil. Cytoskeleton 31: 177-195. [Medline] [CrossRef]

10. Maciver, S. K., Zot, H. G. and Pollard, T. D. 1991. Characterization of actin filament severing by actophorin from Acanthamoeba castellanii. J. Cell Biol. 115: 1611-1620. [Medline] [CrossRef] 
11. Murata, M., Sano, M., Iwashita, T., Sano, M., Naoki, H. and Iwashita, T. 1986. The structure of Pectenotoxin-3, a new constituent of diarrhetic shellfish toxins. Agric. Biol. Chem. 50: 2693-2695.

12. Nakamura, M., Sunagawa, M., Kosugi, T. and Sperelakis, N. 2000. Actin filament disruption inhibits L-type Ca $\left({ }^{2+}\right)$ channel current in cultured vascular smooth muscle cells. Am. J. Physiol. Cell Physiol. 279: C480-C487. [Medline] [CrossRef]

13. Pring, M., Cassimeris, L. and Zigmond, S. H. 2002. An unexplained sequestration of latrunculin A is required in neutrophils for inhibition of actin polymerization. Cell Motil. Cytoskeleton 52: 122-130. [Medline] [CrossRef]

14. Saito, S. and Karaki, H. 1996. A family of novel actin-inhibiting marine toxins. Clin. Exp. Pharmacol. Physiol. 23: 743-746. [Medline] [CrossRef]

15. Saito, S., Watabe, S., Ozaki, H., Fusetani, N. and Karaki, H. 1994. Mycalolide B, a novel actin depolymerizing agent. J. Biol. Chem. 269: 2971029714. [Medline]

16. Saito, S. Y., Hori, M., Ozaki, H. and Karaki, H. 1996. Cytochalasin D inhibits smooth muscle contraction by directly inhibiting contractile apparatus. J. Smooth Muscle Res. 32: 51-60. [Medline] [CrossRef]

17. Saito, S. Y., Watabe, S., Ozaki, H., Kobayashi, M., Suzuki, T., Kobayashi, H., Fusetani, N. and Karaki, H. 1998. Actin-depolymerizing effect of dimeric macrolides, bistheonellide A and swinholide A. J. Biochem. 123: 571-578. [Medline] [CrossRef]

18. Sampath, P. and Pollard, T. D. 1991. Effects of cytochalasin, phalloidin, and pH on the elongation of actin filaments. Biochemistry 30: $1973-1980$. [Medline] [CrossRef]

19. Sasaki, K., Satake, M. and Yasumoto, T. 1997. Identification of the absolute configuration of pectenotoxin-6, a polyether macrolide compound, by NMR spectroscopic method using a chiral anisotropic reagent, phenylglycine methyl ester. Biosci. Biotechnol. Biochem. 61: 1783-1785. [Medline] [CrossRef]

20. Sasaki, K., Takizawa, A., Tubaro, A., Sidari, L., Loggia, R. D. and Yasumoto, T. 1999. Fluorometric analysis of pectenotoxin-2 in microalgal samples by high performance liquid chromatography. Nat. Toxins 7: 241-246. [Medline] [CrossRef]

21. Sato, K., Ozaki, H. and Karaki, H. 1988. Changes in cytosolic calcium level in vascular smooth muscle strip measured simultaneously with contraction using fluorescent calcium indicator fura 2. J. Pharmacol. Exp. Ther. 246: 294-300. [Medline]

22. Spector, I., Shochet, N. R., Kashman, Y. and Groweiss, A. 1983. Latrunculins: novel marine toxins that disrupt microfilament organization in cultured cells. Science 219: 493-495. [Medline] [CrossRef]

23. Spudich, J. A. and Watt, S. 1971. The regulation of rabbit skeletal muscle contraction. I. Biochemical studies of the interaction of the tropomyosintroponin complex with actin and the proteolytic fragments of myosin. J. Biol. Chem. 246: 4866-4871. [Medline]

24. Stossel, T. P. 1989. From signal to pseudopod. How cells control cytoplasmic actin assembly. J. Biol. Chem. 264: 18261-18264. [Medline]

25. Terao, K., Ito, E., Yanagi, T. and Yasumoto, T. 1986. Histopathological studies on experimental marine toxin poisoning. I. Ultrastructural changes in the small intestine and liver of suckling mice induced by dinophysistoxin-1 and pectenotoxin-1. Toxicon 24: 1141-1151. [Medline] [CrossRef]

26. Wendel, H. and Dancker, P. 1986. Kinetics of actin depolymerization: influence of ions, temperature, age of F-actin, cytochalasin B and phalloidin. Biochim. Biophys. Acta 873: 387-396. [Medline] [CrossRef]

27. Word, R. A., Stull, J. T., Casey, M. L. and Kamm, K. E. 1993. Contractile elements and myosin light chain phosphorylation in myometrial tissue from nonpregnant and pregnant women. J. Clin. Invest. 92: 29-37. [Medline] [CrossRef]

28. Yarmola, E. G., Somasundaram, T., Boring, T. A., Spector, I. and Bubb, M. R. 2000. Actin-latrunculin A structure and function. Differential modulation of actin-binding protein function by latrunculin A. J. Biol. Chem. 275: 28120-28127. [Medline]

29. Yasumoto, T. and Murata, M. 1993. Marine Toxin. Chem. Rev. 93: 1897-1909. [CrossRef]

30. Yasumoto, T., Murata, M., Oshima, Y., Matsumoto, G. K. and Clardy, J. 1985. Diarrhetic shellfish toxins. Tetrahedron 41: 1019-1025. [CrossRef]

31. Zhou, Z. H., Komiyama, M., Terao, K. and Shimada, Y. 1994. Effects of pectenotoxin-1 on liver cells in vitro. Nat. Toxins 2: 132-135. [Medline] [CrossRef] 